auditor of state, treasurer of state, register of the state land office, superintendent of public instruction, attorney-general, state librarian, and clerk of the Supreme Court, fucl, lights, ***

TITLE II, CHAP'TER VII.

Supplement to the Code of $100 \%$.

Sec. 164, p. 43. Sureryusion of Captrol-Contracts-Aumitisg of Brus. * * * It (the Executive Council) shall also make for the state all contracts for lighting and repairing the Capitol building and other buildings belonging to the state situate in the city of Des Moines, and grounds connected therewith, ***

TITLE VII, CHAP'TER 1-A.

Supplement to the Code of Iowa, 1919.

Sec. 1400-t5. Leases-Removas of Buirnings. That the Executive Council shall have charge of all buildings that may be on any of the grounds acquired under the provisions of this act and may lease any or all of said buildings and grounds on behalf of the state * * *

Sec. 1400-t2. Alumson Mexorias. Plas. That all buildings, monuments, statuary, memorials, fountains and improvements hereafter erected upon said Capitol grounds shall be located in accordance with the plan covering said extended grounds as contemplated herein submitted as the Allison Memorial Commission plan now on file in the office of the secretary of state, and that said grounds shall be laid out with respect to drives, streets, avenues, malls, walks, bridges, terraces and other improvements in all respects as contemplated and suggested hy said plan and said plan is hereby adopted and made a part of this act.

sec. 1400-t1. Specifics the boundaries of the Capitol extension.

\title{
INDIANS VISIT WASHINGTON IN 1848
}

The Missouri Republican of the 14th inst. notices the arrival at St. Louis of a delegation of head chiefs, braves, \&c., from the Chippewa Indians, residing on territory ceded by them to the United States in the Lake Superior region, on their way to Washington. The object of the mission is said to be to try to procure a grant of land from the government, upon which to settle the nation as citizens of the United States. 'They wish to abandon their roving, wild and vagabond habits, adopt in return the claracteristics and avocations of the white man-to build houses, cultivate farms, etc. It is to be hoped that their disposition to reform may be met in a spirit of philanthropy by the government.-The Bloomington Herald, Bloomington (now Muscatine), Iowa, November 25, 1848. (In the newspaper collection of the Historical, Memorial and Art Department of Iowa.) 
Copyright of Annals of Iowa is the property of State of Iowa, by \& through the State Historical Society of Iowa and its content may not be copied or emailed to multiple sites or posted to a listserv without the copyright holder's express written permission. However, users may print, download, or email articles for individual use. 